\title{
Blended learning using video-based blogs: Public speaking for English as a second language students
}

\author{
Ru-Chu Shih \\ National Pingtung University of Science and Technology
}

\begin{abstract}
With globalisation and the advent of information technology, the English language has become more important for second language (L2) learners. This study aimed to establish a blended teaching and learning model combining online and face to face instructional blogging for an English for specific purposes (ESP) course named English Public Speaking. The research methodology combined qualitative and quantitative approaches and included peer and instructor feedback, interviews, self-reflection, and a learning satisfaction survey. A total of 44 college seniors majoring in English participated in the study. The results of the study showed that this model could contribute to learning effectiveness and student satisfaction if the blended model is implemented with sufficiently supportive equipment and course plans. Most importantly, peer and instructor's feedback and the blog characteristics like free access, ease of revision, and interesting material for learning were major factors that enhanced students' learning satisfaction by motivating them to learn effectively.
\end{abstract}

\section{Introduction}

In an era of internationalisation and globalisation, English has become one of the universal communication tools that connects people. Methods for promoting and enhancing the effectiveness of English teaching and learning have thus become increasingly important for researchers and educators in the field of English language education in Taiwan. The methods for teaching English as a second language, whether in a traditional classroom or a language lab, have gradually changed with the emerging commercialisation of the Internet and the proliferation of information technologies. Abundant multimedia platforms and materials for English language education offer learners and instructors more opportunities for communication and interaction, which may enhance the effectiveness of teaching and learning transactions and thus promote self-directed or self-regulated learning (Wu, Tennyson \& Hsia, 2009; Wu, Tennyson, Hsia \& Liao, 2008).

Due to the globalisation of commerce and education, the ability to speak a second language has become an important skill in workplaces worldwide. In Taiwan, English for Specific Purposes (ESP) is emphasised, in addition to general English education. A review of the topics and themes of English education-related conferences from the past decade in Taiwan shows an increased focus on this area of English language education. As part of efforts to improve the effectiveness of English education, teaching and learning theories and approaches that combine blended learning with Web 2.0 or educational technology have been studied in recent years (Pallos \& Pallos, 2010; Wang, 2009; Wu, 2008; Gupta, 2006). However, applying a blended learning approach with educational technology to ESP courses seems to be a new approach in the field of 
English education. Therefore, the major purposes of this study were (1) to establish an effective blended instruction model for an English Public Speaking course, (2) to investigate the effects of the blended learning model, and (3) to explore English majors' satisfaction with the blended learning approach.

\section{Literature review}

Recent advances in Internet and information technologies have become widely available for use in language teaching and learning. Both online and e-learning activities have continued to expand with alternatives to traditional face to face teaching and learning. Additionally, a significant amount of e-learning research has been devoted to producing e-content, constructing e-learning systems, and integrating technology to improve the learning process. Computer simulations incorporating synchronous chat functions can also motivate language learners who would otherwise be intimidated by face to face interactions to more actively participate (Ranalli, 2008; Freiermuth, 2002). Furthermore, computer assisted language learning can promote collaborative learner-centred knowledge construction and offer a more comfortable and less threatening environment for interaction than that provided by traditional classroom instruction and discussion (Dickson et al., 2008; Warschauer, 1996).

Over the past few years, Internet blogs have emerged as a new communication and publication medium. Blogs offer an exciting new way to deliver individual opinions, share ideas with others, and interact and communicate on the Internet. Derntl and Motschnig-Pitrik (2005) suggested that technology-enhanced learning through customised and parameterised web pages supports learners by, for example, facilitating team building and providing feedback or evaluations, thus reducing the effort expended on organisational issues. Blogs can be used as a collaborative tool for student groups, and instructors can use them as a medium for such tasks as delivering news, messages, and resources, encouraging discussion, and giving feedback and comments (Weller, Pegler \& Mason, 2005).

In past years, scholarship on blogging for language education has revealed some of the tool's impacts and outcomes. Some scholars indicated that blogging enables students to achieve a range of cognitive and social learning outcomes, as well as to develop reflective learning strategies (Birch \& Volkov, 2007; Hourigan \& Murray, 2010; Tan, Ladyshewsky \& Gardner, 2010). Alm (2009) also concluded that blogging can positively affect learners' willingness to communicate by providing them with a personal space where they feel safe to express themselves and to interact with others. In contrast, others argued that insufficient evidence exists to show that blogging improves learning outcomes; thus, more comprehensive and longitudinal studies are therefore needed (Tse, Yuen, Loh, Lam \& Ng, 2010; Farmer, Yue \& Brooks, 2008).

The term "blended learning" often refers to a course methodology or learning activity that combines online and traditional face to face instruction (de Leng et, al., 2010). Online learning is integrated with traditional face to face instruction to create a more effective experience for both instructor and students. So \& Brush (2008) claimed that blended learning is effective in facilitating online collaborative learning. In addition, cooperative learning involves carefully structured activities for group members that allow students to reflect on and evaluate their work in the group, while providing suggestions for improvement (Liao, 2006). Liang (2010) and Warschauer (1996) suggested that online peer feedback as an alternative to face to face communication 
can increase learner motivation, participation, and collaboration. Lee (2008) pointed out that L2 teachers should be aware of their feedback practices' influence on student expectations and attitudes. Additionally, a supportive peer assisted learning environment with interactive feedback can help learners reflect on their professional and evidence based practice (Tan, Ladyshewsky \& Gardner, 2010).

In conclusion, English language teaching no longer consists simply of traditional face to face classroom instruction, even though many educators may be unaware that an integrated approach to language teaching is commonly employed. However, very little research on blended learning has addressed English for Specific Purposes (ESP) in Taiwan, and, more specifically, English Public Speaking courses. Using the combined advantages of face to face instruction, online learning, and collaborative learning, the researcher employed a blended learning model using video-based blogs in an ESP course to explore their effectiveness and to establish an instructional model for educators of English as a second language.

\section{Research framework}

Based on the literature review, the research framework of this study incorporated the following four primary blended learning elements: classroom, instructor, technology, students (CITS) (as shown in Figure 1).

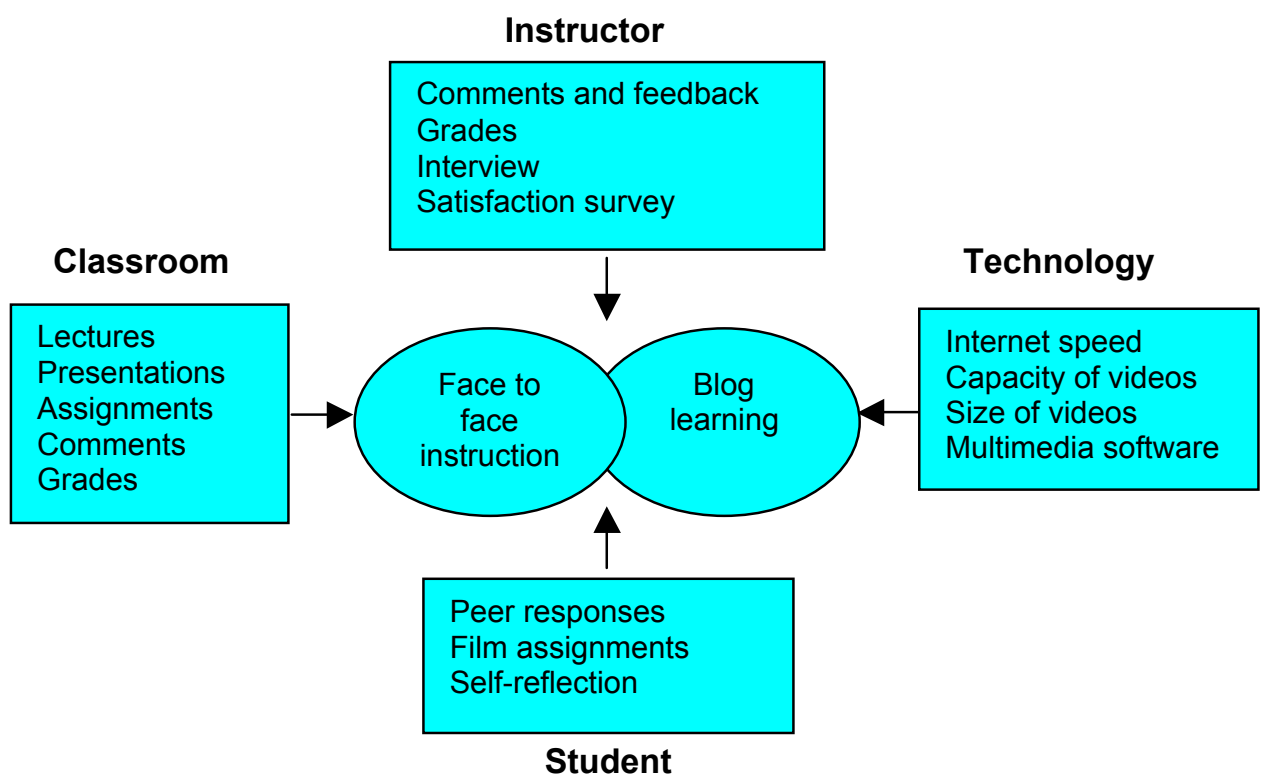

Figure 1: A blended learning model for an English Public Speaking course

\section{Research method}

The research method combined quantitative and qualitative approaches. Data collected from the Blog Learning Satisfaction Survey (BLSS), the peer and instructor comments and feedback, and students' self-reflections were analysed using a quantitative approach. Student interviews were analysed using a qualitative approach. 


\section{Research participants}

A total of 44 senior English majors were enrolled in the required ESP class English Public Speaking. The group was composed of 37 female and 7 male students at a fouryear public university in southern Taiwan. Of these students, 3 males and 3 females volunteered to participate in the interview process during the last week of class. These students were coded as S1-M, S2-F, S3-M, S4-F, S5-M, and S6-F (M represents male; F represents female).

\section{Research instruments}

The research instruments included students' blogs and video clips, student selfreflection sheets, the Blog Learning Satisfaction Survey (BLSS), and the student interview questionnaire.

\section{Students' blogs (in Chinese) and video clips (in English)}

At the beginning of the class, the 44 students in the English public speaking class divided themselves into 9 groups voluntarily. Most of the students were familiar with digital cameras for recording video clips and the majority of them had blogs. Each one of them was required to make a video clip of him or herself making a speech in English and to upload it to their blogs within 7 days. Students were also free to revise or redo their video clips as many times as they desired before the deadline. The length of the video clip was not to exceed five minutes, and the video size was required to be reduced as necessary for uploading. The students could choose their own topic as long as it could be discussed using informative or persuasive speech. The students could write up and practise their own scripts before recording and uploading to the blogs. Also, students were required to comment in Chinese on a comment and discussion board. An example of a student's blog is shown in Figure 2.

\section{The Blog Learning Satisfaction Survey (BLSS) (in Chinese)}

The original survey questionnaire was constructed in Chinese by the researcher and then sent to two scholars in the field for feedback on its contents' validity. These scholars were an assistant professor of English and a professor of Vocational Education. Based on their suggestions, the questionnaire was modified and revised. As a result, the content validity of the BLSS was established.

The BLSS contained two sections that included a total of 44 questions and one open ended question. The first part was composed of demographic information and contained 7 questions, while the second part was composed of 4 domains related to student learning satisfaction, with a total of 37 questions. A five-point (5 to 1) Likert scale, from "strongly agree" to "strongly disagree," was employed to ascertain students' opinions and attitudes regarding statements in the survey questionnaire.

\section{Student interview questionnaire (in English)}

A student interview was conducted in order to obtain more in-depth information on students' opinions about this blended learning course. The questions in the student interview questionnaire were (1) "What do you think of the blended learning model for this course that included both video-based blogging and in class presentations?", 
(2) "What do you suggest that the teacher improve upon?" and (3) "Which part of this course did you like most, and which did you dislike most?"

\section{sumny16866's video}

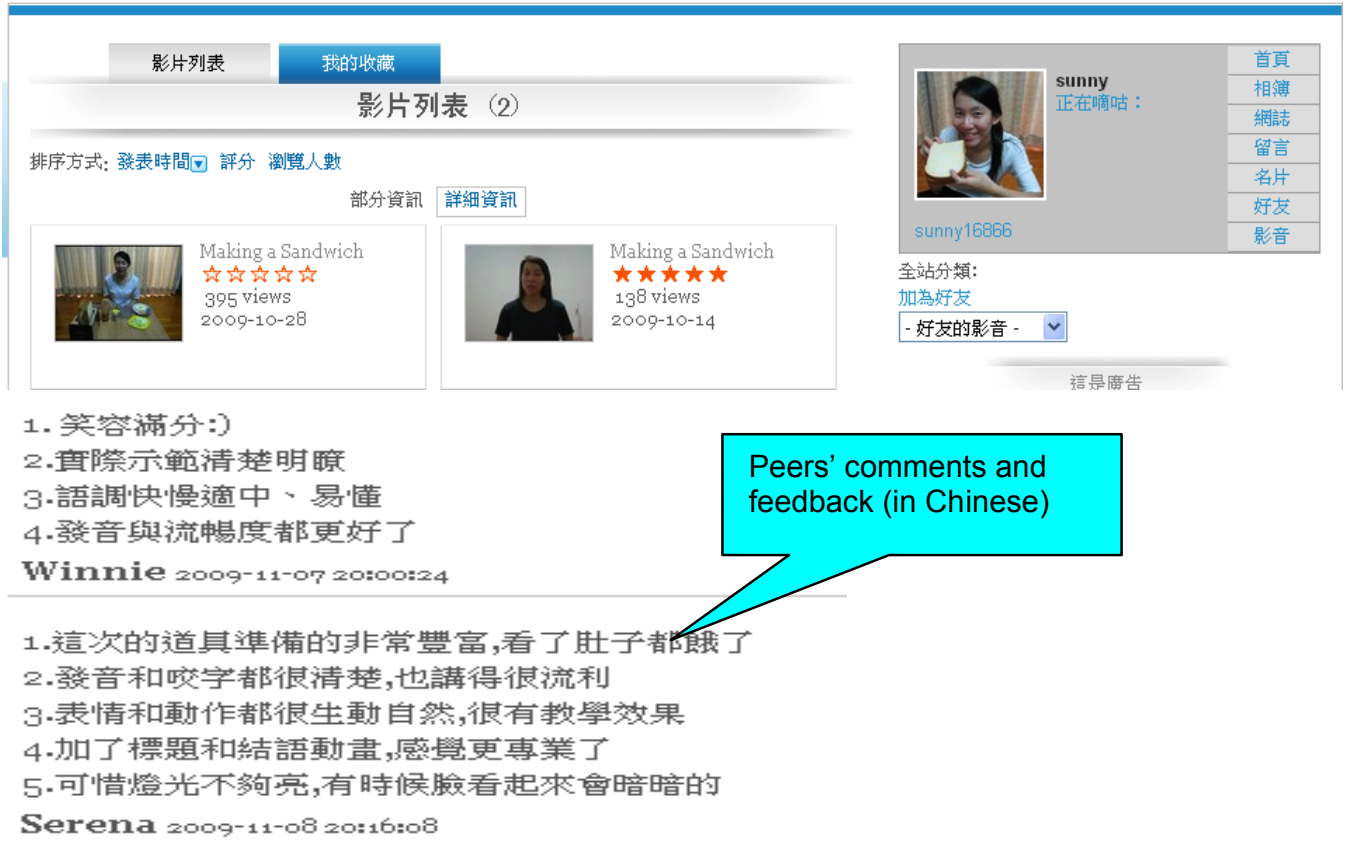

Figure 2: An example of a student's blog

\section{Implementation}

The implementation of the English Public Speaking course was divided into four phases (as shown in Figure 3). This arrangement was intended to facilitate a combination of blogging and face to face $(\mathrm{F} 2 \mathrm{~F})$ instruction.

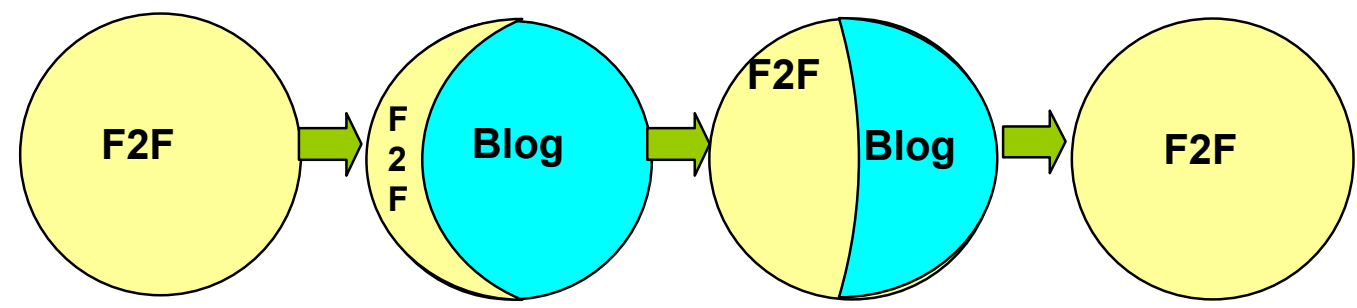

The 1st phase

The 2nd phase

The 3rd phase

The 4th phase

Figure 3: The process of arranging a blended learning model for an English Public Speaking course

The first phase was comprised of traditional face to face instruction for 4 weeks; the second phase started in the 5th week and students were asked to produce and upload video clips to their own blogs within 7 days. In the 6 th week, students were asked to 
comment on their group members' videos on the blogs. Then, the instructor commented on all students' videos. In the 8th week, all students had to upload their revised video clips to the weblogs based on the peer and the instructor comments. The third phase consisted of 2 weeks of evaluating students' progress, and in the 10th week all students' videos were presented to the class. The class would thus be able to engage in live communication and discussion with the instructor about the videos, in addition to commenting on the blogs. To obtain an ideal balance between blog learning and face to face instruction, the 4th phase was comprised of traditional face to -face instruction, including in class individual presentations, lectures, exams, and student interviews.

\section{Results and discussion}

The results and discussion section contains the instructor's evaluation of the students' progress and the students' responses to the interview questionnaire; it also features a statistical analysis of the peer and instructor comments on the videos and the responses to the survey questionnaire.

\section{The analysis of the students' performance progress}

The analysis of students' performance progress differentiated groups with the most progress from those with moderate progress in public speaking performance.

\section{The most progress group}

A group of 36 students $(82 \%)$ did poorly on their first videos. They exhibited a significant number of problems in their first recorded speeches, such as grammatical errors; poor pronunciation; bad camera angles; background noise; speaking too quickly; poor pronunciation, articulation, and content; nervousness; and dull facial expressions. They obtained initial scores between 60 and 70 points based on a scale of 100 points. In their revised videos, however, they showed great improvements in performance, as reflected in the instructor's and their fellow students' comments and feedback. Their speech became more articulate, slower, clearer, and with fewer grammatical errors, the content was better, the camera angle and position correct, and their facial expressions and gestures appropriate.

\section{The moderate progress group}

In the moderate progress group, 8 students (18\%) progressed moderately on their revised speeches. They only showed slight improvements in camera angles, background noise, posture, and gestures in those revised videos. However, these students only required small modifications and adjustments to their speeches. Figure 4 shows the blog pictures of the video clips from a student's performance. The student made significant progress in her videos. The initial video was upside down; the camera position was too far from the subject, the student's pronunciation and intonation were improper, and her gestures and facial expressions were not appropriate. In the revised video, those weaknesses were addressed, and performance improved.

In summary, blogging technology allowed students to see their own performances, thus recognising their own oral skill, posture, gestures, and facial expressions. In addition, they were able to improve weaknesses and to learn from others' strengths by watching videos on the blogs repeatedly. 

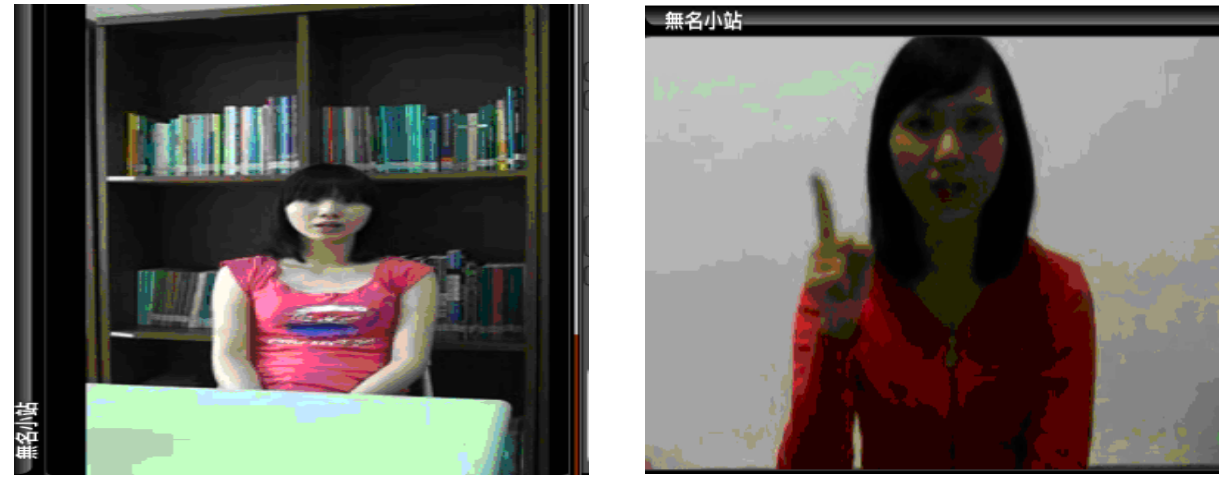

Figure 4: Blog pictures of a student's public speaking performance

\section{Statistical analysis of comments on the videos from peers and the instructor}

The 44 students in the 9 groups all made comments in Chinese about their group members' first videos. Comments and suggestions on the blogs from both the instructor and the peers were collected and ranked by frequency (as shown in Figure 5 ). The areas pinpointed were enunciation, articulation and grammatical errors, volume of voice, facial expression, gesture and posture, the quality of the video, and background noise. In summary, the comments on the videos show that blog learning can improve not only professional skills but also familiarity with blog applications.

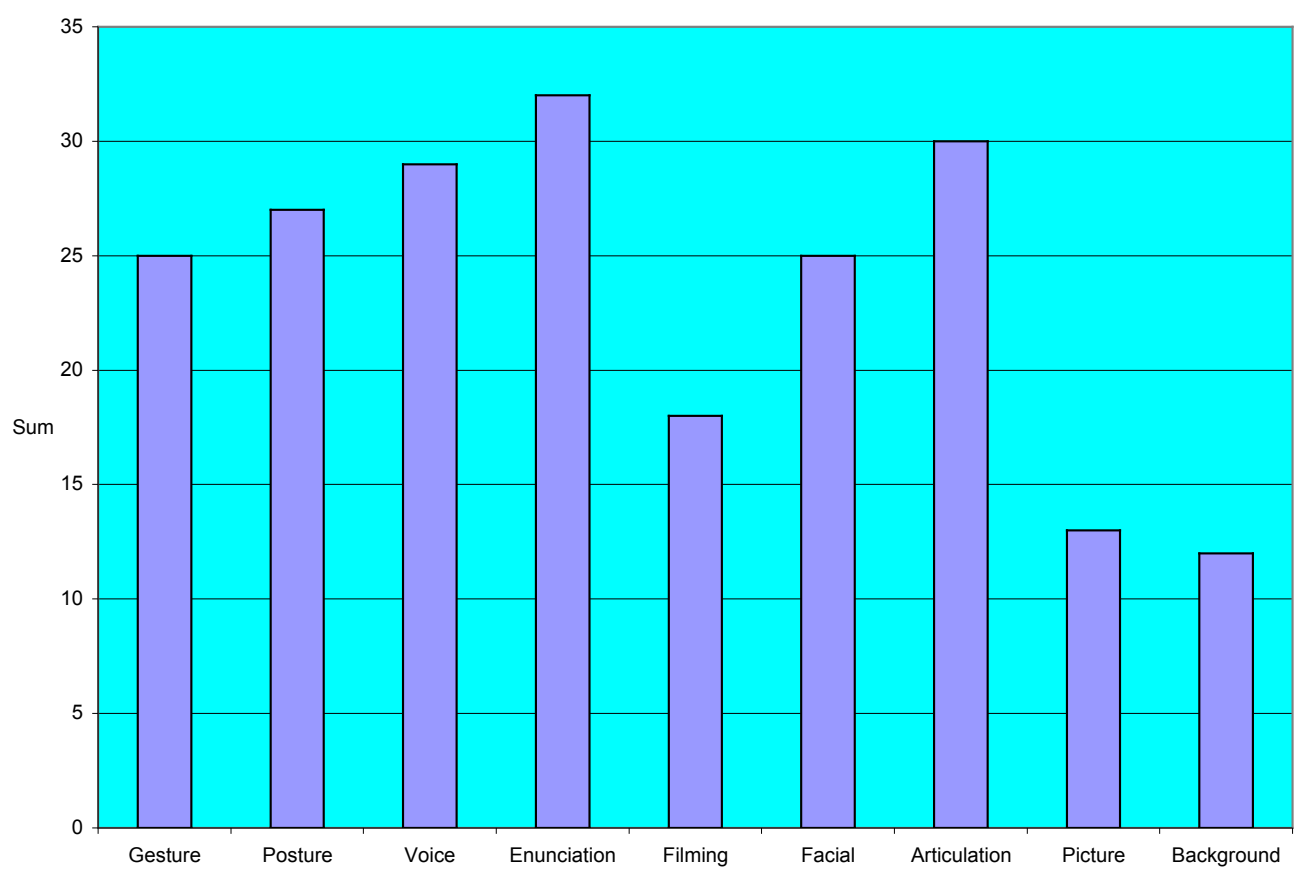

Figure 5: The frequency of peer and the instructor's comments on the videos 


\section{Statistical analysis of the responses to the survey questionnaire}

The collected survey questionnaire obtained a Cronbach alpha of .930, indicating the survey questionnaire's reliability. Table 1 shows the descriptive results of the students' responses to the survey questionnaire. Among the 44 returned questionnaires, 2 were incomplete and invalid. Thus, the researcher only computed the results for 42 questionnaires. The mean scores of the 37 questions ranged from 3.10 to 4.50 with acceptable standard deviations; thus, all students displayed high levels of agreement regarding the statements in the survey questionnaire.

Table 1: Descriptive results for students' responses to the survey questionnaires $(\mathrm{N}=42)$

\begin{tabular}{|c|c|c|c|c|}
\hline \multicolumn{2}{|l|}{ No. } & Statement & Mean & SD \\
\hline \multirow{7}{*}{$\begin{array}{l}\text { I. Design of } \\
\text { the blog and } \\
\text { videos }\end{array}$} & 1 & $\begin{array}{l}\text { Type and size of font on the blog may influence my willingness } \\
\text { to use the weblog for public speaking. }\end{array}$ & 3.71 & .918 \\
\hline & 2 & $\begin{array}{l}\text { Line spacing and clear paragraph arrangement may influence } \\
\text { my willingness to use the blog for public speaking. }\end{array}$ & 3.76 & .906 \\
\hline & 3 & $\begin{array}{l}\text { The fonts and colors used on the blog interface may influence } \\
\text { my willingness to use the blog for public speaking. }\end{array}$ & 3.86 & .899 \\
\hline & 4 & $\begin{array}{l}\text { The configuration of the uploaded video may influence my } \\
\text { willingness to use the blog for public speaking. }\end{array}$ & 3.62 & .936 \\
\hline & 5 & $\begin{array}{l}\text { The file size of the video may influence my willingness to use the } \\
\text { blog for public speaking. }\end{array}$ & 3.74 & .857 \\
\hline & 6 & $\begin{array}{l}\text { The speed at which I can upload a video may influence my } \\
\text { willingness to use the blog for public speaking. }\end{array}$ & 4.24 & .692 \\
\hline & 7 & $\begin{array}{l}\text { The topic of the speech may influence my willingness to use the } \\
\text { blog for public speaking. }\end{array}$ & 3.88 & .942 \\
\hline \multirow{7}{*}{$\begin{array}{l}\text { II. Opinions } \\
\text { about the } \\
\text { blog } \\
\text { platform }\end{array}$} & 8 & It is easy to use the blog to learn public speaking techniques. & 3.71 & .835 \\
\hline & 9 & $\begin{array}{l}\text { Using the blog to learn public speaking is helpful because there } \\
\text { is no time limit. }\end{array}$ & 4.19 & .773 \\
\hline & 10 & $\begin{array}{l}\text { Using the blog to learn public speaking is helpful because there } \\
\text { is no space limit. }\end{array}$ & 3.69 & .924 \\
\hline & 11 & $\begin{array}{l}\text { That it is free to use the blog to learn public speaking is a great } \\
\text { advantage. }\end{array}$ & 4.29 & .596 \\
\hline & 12 & $\begin{array}{l}\text { The blog's large capacity makes it helpful for learning public } \\
\text { speaking. }\end{array}$ & 4.33 & .570 \\
\hline & 13 & $\begin{array}{l}\text { The stability of the blog system can be helpful for learning public } \\
\text { speaking. }\end{array}$ & 3.10 & 932 \\
\hline & 14 & $\begin{array}{l}\text { The multiple functions of the blog platform can facilitate } \\
\text { learning public speaking. }\end{array}$ & 3.76 & .850 \\
\hline \multirow{8}{*}{$\begin{array}{l}\text { III. Learning } \\
\text { attitudes } \\
\text { toward } \\
\text { blogging }\end{array}$} & 15 & $\begin{array}{l}\text { I hope that the instructor can continue to combine the blog with } \\
\text { traditional teaching to teach public speaking. }\end{array}$ & 4.10 & .821 \\
\hline & 16 & $\begin{array}{l}\text { Combining the blog with traditional teaching can enhance my } \\
\text { motivation to learn public speaking. }\end{array}$ & 3.83 & .853 \\
\hline & 17 & $\begin{array}{l}\text { Combining the blog with traditional teaching can enhance my } \\
\text { motivation to learn about multimedia computer resources. }\end{array}$ & 3.88 & .942 \\
\hline & 18 & $\begin{array}{l}\text { I like using the blog to learn public speaking more than using the } \\
\text { traditional teaching method. }\end{array}$ & 4.05 & .936 \\
\hline & 19 & $\begin{array}{l}\text { I have changed my attitude and perspective toward public } \\
\text { speaking due to blog learning. }\end{array}$ & 4.21 & .842 \\
\hline & 20 & $\begin{array}{l}\text { I can overcome my stage fright through blog learning about } \\
\text { public speaking. }\end{array}$ & 3.95 & .882 \\
\hline & 21 & $\begin{array}{l}\text { I feel more confident about public speaking after engaging in } \\
\text { blog learning. }\end{array}$ & 3.86 & .783 \\
\hline & 22 & I think it is interesting to learn public speaking using a blog. & 4.19 & .890 \\
\hline
\end{tabular}




\begin{tabular}{|c|c|c|c|c|}
\hline \multirow{15}{*}{$\begin{array}{l}\text { IV. Learning } \\
\text { effectiveness } \\
\text { of the blog } \\
\text { application }\end{array}$} & 23 & $\begin{array}{l}\text { The instructor's comments on my blog can help me to improve } \\
\text { my public speaking performance. }\end{array}$ & 4.14 & .647 \\
\hline & 24 & $\begin{array}{l}\text { Group members' comments on my blog can help me to improve } \\
\text { my public speaking performance. }\end{array}$ & 4.21 & .606 \\
\hline & 25 & $\begin{array}{l}\text { Imitating and reviewing group members' videos can help me to } \\
\text { improve my rhetoric in public speaking. }\end{array}$ & 4.17 & .696 \\
\hline & 26 & $\begin{array}{l}\text { Imitating and reviewing group members' videos can help me to } \\
\text { improve the organisation of my public speaking. }\end{array}$ & 4.24 & .759 \\
\hline & 27 & $\begin{array}{l}\text { Imitating and reviewing group members' videos can help me to } \\
\text { improve my enunciation. }\end{array}$ & 4.38 & .661 \\
\hline & 28 & $\begin{array}{l}\text { Imitating and reviewing group members' videos can help me to } \\
\text { improve my pronunciation and intonation. }\end{array}$ & 4.31 & .643 \\
\hline & 29 & $\begin{array}{l}\text { Imitating and reviewing group members' videos can help me to } \\
\text { improve voice volume in speech. }\end{array}$ & 4.14 & .783 \\
\hline & 30 & $\begin{array}{l}\text { Imitating and reviewing group members' videos can help me to } \\
\text { improve my posture and gesture }\end{array}$ & 4.45 & .670 \\
\hline & 31 & $\begin{array}{l}\text { Imitating and reviewing group member's videos can help me to } \\
\text { improve my articulation. }\end{array}$ & 4.12 & .739 \\
\hline & 32 & $\begin{array}{l}\text { Imitating and reviewing group members' videos can help me to } \\
\text { improve my public speaking performance. }\end{array}$ & 4.24 & .790 \\
\hline & 33 & $\begin{array}{l}\text { Reviewing and revising my own video can help me to under- } \\
\text { stand my own strengths and weaknesses in public speaking. }\end{array}$ & 4.50 & .552 \\
\hline & 34 & $\begin{array}{l}\text { Imitating and reviewing group members' videos can help me to } \\
\text { address my own weaknesses. }\end{array}$ & 4.40 & .734 \\
\hline & 35 & $\begin{array}{l}\text { Through blog learning about public speaking, I can also increase } \\
\text { my ability to use computer applications. }\end{array}$ & 3.90 & .850 \\
\hline & 36 & $\begin{array}{l}\text { Through blog learning about public speaking, I can also improve } \\
\text { my communication with my classmates. }\end{array}$ & 4.07 & .808 \\
\hline & 37 & $\begin{array}{l}\text { Through blog learning about public speaking, I can also improve } \\
\text { my interpersonal skills and relationships with my classmates. }\end{array}$ & 3.90 & .906 \\
\hline
\end{tabular}

The statistical results of the satisfaction survey questionnaire are analysed according to the four domains, as follows. Domain I obtained moderately high mean scores, ranging from 3.71 to 4.24 , which indicates that students possessed a high level of agreement with the survey statements. Particularly, Question 6, "The speed at which I can upload a video may influence my blog learning willingness for public speaking," obtained a high mean score of 4.24, indicating that students thought that the speed of uploading videos is a critical issue that may influence their satisfaction with blog learning and willingness to engage in it. Domain II, "Opinions about the blog platform," obtained mean scores ranging from 3.10 to 4.33 , which indicates that students experienced a high level of agreement with the questions. Questions 12,11, and 9 obtained the higher mean scores of 4.33,4.29, and 4.19, respectively, indicating that students valued the chosen blog for having a larger capacity, being free, and having no time limit.

Domain III, "Learning attitudes toward blogging," obtained mean scores ranging from 3.83 to 4.21 , which indicates that students possessed moderately high levels of agreement and positive learning attitudes toward blogging. Questions 19, 22, and 15 obtained the high mean scores of 4.21, 4.19, and 4.10, respectively, indicating that students thought that blogging had changed their attitudes toward and perspectives on learning public speaking and that learning public speaking through blogging was interesting. In addition, students preferred a blended teaching and learning approach in the public speaking class. Domain IV, "Learning effectiveness of the blog applications," obtained high mean scores ranging from 3.90 to 4.50 , indicating that students possessed positive attitudes toward using blog learning for public speaking 
and agreed that it was very effective for learning. In particular, Question 33, "Reviewing and revising my own videos can help me to understand my own strengths and weaknesses in public speaking," obtained the high mean score of 4.50, indicating that students highly valued the review and revision function of the blog.

To conclude, moderate to high average mean scores on the 37 statements in the learning satisfaction survey completed by the 44 students indicate that students possessed positive attitudes toward the blended learning model.

\section{Analysis of students' self-reflection}

The statistical results of the students' self-reflections are listed in Tables 2 and 3. Similar comments by at least 10 students are summarised, and their frequency is listed. Tables 2 and 3 show the students' self-reflection on the advantages and disadvantages of using blended learning in the English Public Speaking course.

Table 2: Students' self-reflections on the advantages of using blog learning for public speaking

\begin{tabular}{|c|l|c|}
\hline Rank & \multicolumn{1}{|c|}{ Comments } & \multicolumn{1}{|c|}{ Frequency } \\
\hline 1. & $\begin{array}{l}\text { By pinpointing a video's strengths and weaknesses, peer reviewers can help } \\
\text { me to correct the content of my videos. }\end{array}$ & 15 \\
\hline 2. & $\begin{array}{l}\text { Making a video at home is more time-flexible than making one in class. When } \\
\text { we made mistakes or forgot what to say, we were able to redo it. }\end{array}$ & 12 \\
\hline 3. & $\begin{array}{l}\text { A blog video clip can help me observe my peers' and my strengths and } \\
\text { weaknesses (like pronunciation or facial expressions) and to review them } \\
\text { repeatedly. }\end{array}$ & 10 \\
\hline 4. & $\begin{array}{l}\text { Making a self-created video for my own blog is very interesting and is a new } \\
\text { way of learning public speaking. }\end{array}$ & 10 \\
\hline 5. & $\begin{array}{l}\text { We can obtain helpful comments or suggestions not only from our instructor } \\
\text { but also from our peers. }\end{array}$ \\
\hline
\end{tabular}

According to Table 2, “By pinpointing a video's strengths and weaknesses, peer reviewers can help me to correct the content of my videos" obtained the greatest frequency; indicating that most students felt more comfortable giving and receiving feedback among their close friends or peers, which is consistent with the idea that peer feedback and interaction can improve motivation and the effectiveness of language learning (Derntl \& Motschnig-Pitrik, 2005; Hiltz \& Turoff, 2002). The second most frequently mentioned item was "Making a video at home is more time-flexible than making one in class. When we made mistakes or forgot what to say, we were able to redo it." These results indicate that most students preferred using a blog to create a video that they could redo as many times as they liked, which is consistent with ideas regarding the convenience and ease of making a blog video clip. The third most frequently mentioned item was "A blog video clip can help me observe my peers' and my strengths and weaknesses (like pronunciation or facial expressions) and to review them repeatedly." This result shows that a blog can not only record the content of a speech but also be viewed repeatedly, indicating that it retains content, can be replayed, and is easy to use.

According to Table 3 "Students' self-reflection on the advantages of using blog learning for public speaking," the most frequent disadvantages of blog were "When the size of the video is too large, it is very difficult and time-consuming to upload it to the blog" $(n=19)$, "Video-making takes a lot of time because when I am too nervous or forget 
what to say, I have to try again." ( $\mathrm{n}=12)$, and "The blog videos lack the sensation of being face to face." ( $n=11)$. These results indicate that the capacity and size of the videos, the uploading and downloading speeds, and the time requirements for making the videos were major concerns for students using blogs to learn public speaking. In addition, some students pointed out that spending too much time on learning to record videos may decrease the time spent on practising and overcoming their stage fright.

Table 3: Students' self-reflection on the disadvantages of using blog learning for public speaking

\begin{tabular}{|c|c|c|}
\hline Rank & Comments & Frequency \\
\hline 1. & $\begin{array}{l}\text { When the size of the video is too large, it is very difficult and time-consuming } \\
\text { to upload it to the blog. }\end{array}$ & 19 \\
\hline 2. & $\begin{array}{l}\text { Video-making takes a lot of time because when I am too nervous or forget } \\
\text { what to say, I have to try again. }\end{array}$ & 12 \\
\hline 3. & The blog videos lack the sensation of being face to face. & 11 \\
\hline
\end{tabular}

\section{Student interview}

During the last week of the class, the researcher interviewed six volunteer students to obtain in depth feedback on the blended learning class. The interview questions are listed as follows, followed by the students' responses and discussions (in English).

1. What do you think of the blended learning model for this course that included both videobased blogging and in class presentations?

I think it's better than just having the blog video. You can see the video on the blog then you can learn how to speak better. (S1-M)

I think it's great for student to improve their learning motivation and make them more interesting but choosing the right and modest video is important. (S2-F)

I think video should be included in this course. Many company want people to send their introduction by using video. I think we can get more advice from this course. (S3-M)

I think we can have blog video whole semester. (S4-F)

I agree these two ideas because these two ideas got different advantages. First, if we use blog video, we can train us not to be afraid by standing or sitting front the camera. The other one is can train us not to be afraid by standing in front the people when you do a speech. I think those idea can be very helpful when we do a speech. And it's a good way to train our courage. I totally agree with these two ideas. (S5-M)

I think it is easy for me through blog video. There are many chances to practice the speech. Although it is more nervous in class presentation, I think it is a good way to train us to be brave in front of people. We can also see our own strengths and weakness and others as well. (S6-F)

According to the students' interview responses, the six students all expressed positive attitudes toward the blended learning model using video-based blogs to teaching public speaking. They all strongly agreed on the effectiveness of blog applications for teaching public speaking. Notably, S5-M pointed out that using a video to learn public speaking could help to ease stage fright or to overcome fear or nervousness. However, S6-F presented the opposite idea. S6-F preferred having more on site/in class practice 
in using a blog and recording public speaking. Four of them mentioned that they could obtain advice from group members about how to improve their speeches as well as learn from other students by reviewing other members' videos.

\section{What do you suggest that the teacher improve upon?}

I think teacher should teach students how to use software related to the film such as transforming the format. (S1-M)

The teacher should teach the student not only their pronunciation and gesture they perform but also the content the talk. So I suggest the teacher should give more advice about it. (S2-F)

Teacher can teach how to present self better, for example, how to choose background, voice volume, and something like that. (S3-M)

I think having weblog film is better than in class presentation. ... hope teachers can continue this kind of course. (S4-F)

Teacher can give us more explain or analyse our weakness when we do a speech. Or tell us which skills should we improve or reinforce when we do a speech. (S5-M)

S6-F had no suggestions regarding how to improve the class. The majority of the students indicated that they could learn professional public speaking skills such as facial expressions, pronunciation, intonation, voice volume, quality of video, and presentation from other group members' performance and from their advice and suggestions. Most of them also mentioned that the instructor's comments and suggestions were very useful and beneficial, helping them to improve their public speaking performance.

3. Which part of this course did you like most, and which did you dislike most?

I like the way for students to have this interesting way learning speech. It's new and fun. Sometimes may be boring, I think two parts may be better. I like we can use weblog at home anytime. But I don't like the slow uploading. It took me too much time. (S1-M)

I like most are going to the stage and face the audiences which help me conquer stage fright... and teacher gave some suggestions about me speech. The dislike part is less opportunities to go on the stage, because the students are too many, and only once a week, even more. I suggest teacher should give student speech homework every week. (S2-F)

I like the half weblog film. It's very interesting and new. In this model, I won't be very nervous and I also can learn from other people by surfing their blog. I also can prepare well. (S3-M)

After full prepared, we can shoot the better film and won't feel too nervous when we present. (S4-F)

I think I like to use weblog to present a speech than present in class. We can see our face emotion when we do a speech through the camera. Sometimes you can find your mouth is curved when you saying words or sentences. So that you can know you have to improve that. It is a perfect way that you can know when you saying English you may have ugly face. (S5-M)

I like to use weblog film most and it's fun. However, if the film capacity is too big, it will waste too much time to wait for uploading. (S6-F) 
Based on the results above, what the students liked most in the public speaking course was that the blended approach was interesting, fun, flexible to use, and easy to adjust, modify or review as many times as they wanted, which was in accordance with the results of the survey and students' self-reflections. This blended approach also helped them to understand their and others' strengths and weaknesses in public speech presentation. In addition, students indicated that they liked the blended learning approach because it not only offered them the chance to overcome their stage fright but also enhanced their learning motivation and cooperative learning with peers, and improved their performance through the aforementioned elements of review and commentary.

To summarise, based on students' self-reflection, 19 students $(43 \%)$ agreed that recording and uploading the videos can be very time-consuming if their Internet speed is not fast enough or the size of the video too large. Twelve students $(27 \%)$ agreed that video recording can be frightening to them. Eleven students $(25 \%)$ agreed that video recording reduced the benefits of face to face practice, which could hinder their progress and practice. These results are consistent with the responses from the student interview. In order to solve this problem of reduced face to face practice, a balanced instruction plan should be carefully designed beforehand. Both face to face in class instruction and blogging should be equally distributed and mastered for the public speaking course.

The blended learning approach for the public speaking course has the advantage of offering students a range of opportunities and ways to improve their professional public speaking skills, which include their grammar, pronunciation, posture, gestures, facial expressions, eye contact, video recording techniques, and computer media applications. On the other hand, blended learning may cause disadvantages such as, for example, that students' levels of knowledge of computer media applications might affect their blogging. Additionally, students' computer and camera hardware, software, and related equipment might influence the quality of the videos and thus affect their interest, motivation, and performance in public speaking, as students pointed out in the interview.

\section{Conclusion and suggestions}

As Ranlli (2008) pointed out, computer assisted simulation and learning activities for language learning can help to foster cooperative learning among students and to enhance opportunities for language use. The results of this study show that such educational goals have been achieved, confirming the effectiveness of the blended learning model using video-based blogs for an ESP course in public speaking, through a series of thorough research design and execution procedures. The findings of the study are discussed and presented as follows:

1. A blended learning model using video-based blogs could be an effective approach for L2 learners to learn public speaking productively and efficiently. Students expressed great appreciation for, interest in, and satisfaction with the blended learning course.

2. Blogging helped $82 \%$ of students improve their professional public speaking skills, such as enunciation, articulation, facial expressions, posture, and gestures.

3. Students also learned how to use computer multimedia software and blogging applications through cooperative learning. 
4. Students were able to view and correct their own weaknesses and to learn from others' strengths by watching videos in blogs repeatedly. These advantages are not generally available in traditional face to face instruction.

5. By implementing blended learning to the public speaking course, students can benefit from self-autonomous and collaborative learning, peer feedback on videos, reviews of peers' and their own videos, the instructor's feedback (both synchronous and asynchronous), and self-reflection.

On the other hand, before implementing this type of blended learning in an ESP course, the following issues should be considered:

1. The class arrangement and planning for blended learning are critical to the success of the class implementation.

2. The file size of the video, Internet speed, and availability of video cameras are important for students, which may influence students' interests in learning public speaking.

3. Instructors should be concerned about the proper timing for implementing the blended learning model to an ESP course.

4. The blended learning model is not limited to use in ESP courses but may also be used in other educational programs by educators, L2 teachers, and administrators to balance and optimise course instruction and class activities.

Finally, this study provides evidence that a blended learning model using video-based blogs can be a valuable and effective way to facilitate ESP instructors to obtain better educational outcomes. Hopefully the results will inspire future work on other courses at the college level and improve language education, especially for ESP.

\section{Acknowledgments}

The author gratefully acknowledges Dr Shi-Jer Lou, Professor, Graduate Insititute of Technogical and Vocational Education, NPUST for his advice, support, and guidance in the development of this paper.

\section{References}

Birch, D. \& Volkov, M. (2007). Assessment of online reflections: Engaging English second language (ESL) students. Australasian Journal of Educational Technology, 23(3), 291-306. http: / / www.ascilite.org.au/ajet/ajet23/birch.html

de Leng, B. A., Dolmans, D. H. J. M., Donkers, H. L. M., Muijtjens, A. M. M. \& van der Vleuten, C. P. M. (2010). Instruments to explore blended learning: Modifying a method to analyze online communication for the analysis of face-to-face communication. Computers $\mathcal{E}$ Education, $55,644-651$.

Derntl, M. \& Motschnig-Pitrikm R. (2005). The role of structure, patterns, and people in blended learning. The Internet and Higher Education, 8, 111-130

Dickinson, M., Eom, S., Kang, Y., Lee, C. H. \& Sachs, R. (2008). A balancing act: how can intelligent computer-generated feedback be provided in learner-to-learner interactions? Computer Assisted Language Learning, 21(4), 369-382.

Farmer, B., Yue, A. \& Brooks, C. (2008). Using blogging for higher order learning in large cohort university teaching: A case study. Australasian Journal of Educational Technology, 24(2), 123-136. http: / / www.ascilite.org.au/ajet/ajet24/ farmer.html 
Freiermuth, M. (2002). Connecting with computer science students by building bridges. Simulation E Gaming, 3(3), 299-315.

Gupta, R. (2006). Learning from our students: Technology in the ESP classroom. Internet Journal of e-Language Learning $\mathcal{E}$ Teaching, 3(2), 14-27.

Hourigan, T. \& Murray, L. (2010). Using blogs to help language students to develop reflective learning strategies: Towards a pedagogical framework. Australasian Journal of Educational Technology, 26(2), 209-225. http:/ / www.ascilite.org.au/ajet/ajet26/hourigan.html

Lee, L (2008). Focus-on-form through collaborative scaffolding in expert-to-novice online interaction. Language Learning \& Technology, 12(3), 53-72. http: / /lit.msu.edu/vol12num3/lee.pdf

Ranalli, J. (2008). Learning English with The Sims: Exploiting authentic computer simulation games for L2 learning. Computer Assisted Language Learning, 21(5), 441-455.

So, H. J. \& Brush, T. A. (2008). Student perceptions of collaborative learning, social presence and satisfaction in a blended learning environment: Relationships and critical factors. Computers E Education, 51, 318-336.

Tan, S. M., Ladyshewsky, R. K. \& Gardner, P. (2010). Using blogging to promote clinical reasoning and metacognition in undergraduate physiotherapy fieldwork programs. Australasian Journal of Educational Technology, 26(3), 355-368.

http: / / www.ascilite.org.au/ajet/ajet26/tan.html

Liao, Y. L. (2006). A comparative study of responses of teachers and students in middle schools to a cyber fair program. The 23rd International Conference on English Teaching and Learning in the Republic of China: Changes, chances, and challenges in English teaching and learning, 2, pp.786-802.

Liang, M. Y. (2010). Using synchronous online peer response groups in EFL writing: Revisionrelated discourse. Language Learning \& Technology, 14(1), 45-65. http: / / llt.msu.edu/vol14num1/liang.pdf

Tse, S. K., Yuen, A. H. K., Loh, E. K. Y., Lam, J. W. I. \& Ng, R. H. W. (2010). The impact of blogging on Hong Kong primary school students' bilingual reading literacy. Australasian Journal of Educational Technology, 26(2), 164-179.

http: / / www.ascilite.org.au/ajet/ajet26/tse.html

Warschauer, M. (1996). Comparing face-to-face and electronic discussion in the second language classroom. CALICO Journal, 13(2), 7-26.

Well, M., Pegler, C. \& Mason, R. (2005). Use of innovative technologies on an e-learning course. The Internet and Higher Education, 8, 61-71.

Wang, M. J. (2009). Web based projects enhancing English language and generic skills development for Asian hospitality industry students. Australasian Journal of Educational Technology, 25(5), 611-626. http:/ / www.ascilite.org.au/ajet/ajet25/wang.html

Wu, W. S. (2008). The application of Moodle on an EFL collegiate writing environment. Journal of Education and Foreign Languages and Literature, 7, 45-56. [verified 18 Oct 2010] http: / / people.chu.edu.tw/ wswu/ publications / papers/ journals/06.pdf

Wu, J. H., Tennyson, R. D. \& Hsia, T. L. (2010). A study of student satisfaction in a blended elearning system environment. Computers $\mathcal{E}$ Education, 55(1), 155-164.

Dr Ru-Chu Shih, Assistant Professor, Department of Modern Languages

National Pingtung University of Science and Technology, 1 Shuefu Road, Neipu,

Pingtung 912, Taiwan. Email: vincent@npust.edu.tw 